\title{
Penyuluhan Pembuatan Pakan Lengkap Terfermentasi untuk Mengurangi Intensitas Ngarit di Desa Gunungpring, Kecamatan Muntilan, Kabupaten Magelang
}

\section{Counseling of Fermented Complete Feed Making to Reduce Grass Cutting Intensity in Gunungpring Village, Muntilan Sub-District, Magelang District}

\author{
Mohamad Haris Septian ${ }^{1, a}$, Nur Hidayah ${ }^{1}$, Ayu Rahayu ${ }^{1}$ \\ ${ }^{1}$ Program Studi Peternakan, Fakultas Pertanian, Universitas Tidar \\ aemail: mharisseptian@untidar.ac.id
}

\begin{abstract}
Abstrak
Kurangnya ketersediaan pakan di Desa Gunungpring membuat peternak di desa tersebut kesulitan untuk mencukupi kebutuhan pakan. Berdasarkan survey awal ditemukan rendahnya pengetahuan peternak mengenai manajemen pemeliharaan dan penyediaan pakan pakan ternak. Oleh karenanya dilakukan penyuluhan untuk meningkatkan pengetahuan dan keterampilan masyarakat mengenai manajemen pemeliharaan dan penyediaan pakan ternak dengan metode pengolahan pakan komplit terfermentasi untuk domba dan kambing. Sasaran pelaksanaan kegiatan adalah Kelompok Tani Ternak Karya Makmur Desa Gunungpring, Kecamatan Muntilan, Kabupaten Magelang. Metode Penyuluhan adalah ceramah dan praktikum. Peserta yang mengikuti kegiatan ini sebanyak 15 orang peternak ditambah 10 orang mahasiswa Program Studi Peternakan Fakultas Pertanian, Universitas Tidar. Berdasarkan evaluasi yang dilakukan setelah proses penyuluhan, dapat disimpulkan bahwa adanya peningkatan pengetahuan peternak sebesar $18,66 \%$ mengenai manajemen pemeliharaan, peningkatan pengetahuan mengenai jenis-jenis bahan pakan dan hijauan pakan sebesar 36,67\%, peningkatan pengetahuan mengenai pakan fermentasi sebesar $30 \%$, peningkatan pengetahuan mengenai pakan komplit terfermentasi sebesar $53,37 \%$, peningkatan pengalaman membuat pakan fermentasi sebesar $20 \%$, dan intensitas ngarit yang berkurang sebesar 33,33\%, kerta keberlangsungan kegiatan yang rutin dilakukan oleh peternak. Kelompok Tani Ternak Karya Makmur mampu membuat pakan lengkap terfermentasi, serta mengaplikasikannya secara berkelanjutan.
\end{abstract}

Kata kunci: manajemen pemeliharaan, pakan lengkap terfermentasi, domba, kambing, Gunungpring.

\begin{abstract}
The lack of feed availability in Gunungpring makes it difficult for farmers in the village to meet their feed needs. Based on the survey, it was found that farmers' knowledge was low regarding the management of maintenance and provision of animal feed. Therefore, counselling was carried out to increase the knowledge and skills of the community regarding the management of maintenance and provision of animal feed using a fermented complete feed processing method for sheep and goats. The target of this activity is the Karya Makmur Animal Farmers Group in Gunungpring Village, Muntilan Sub-District, Magelang District. Participants who took part in this activity were 15 farmers plus 10 students from the Animal Husbandry Study Program, Faculty of Agriculture, Tidar University. Based on the evaluation carried out after the extension process, the result concluded that there is an increase in farmer knowledge of $18.66 \%$ regarding maintenance management, an increase in knowledge of the types of feed ingredients and forage by $36.67 \%$, an increase in knowledge of fermented feed by $30 \%$, increased knowledge about fermented complete feed by $53.37 \%$, increased experience for making fermented feed by $20 \%$, and reduced grass cutting intensity by $33.33 \%$, as well as sustainability of activities routinely carried out by farmers.
\end{abstract}

Key words: maintenance management, fermented complete feed, sheep, goats, Gunungpring 


\section{Pendahuluan}

Peternak Desa Gunungpring mengeluhkan ketersediaan pakan ternak, khususnya hijauan pakan. Keterbatasan lahan hijauan pakan menjadi penyebab utama ditambah dengan musim kemarau yang berkepanjangan sehingga hijauan pakan sulit didapat. Kesulitan tersebut membuat peternak menggunakan batang pisang sebagai pakan ternak. Batang pisang dinilai tidak dapat mencukupi kebutuhan zat makanan bagi ternak dikarenakan kandungan ligninnya yang terlalu tinggi dan protein kasarnya yang rendah.

Batang pisang sendiri kandungan zat makanannya sangat rendah. Berdasarkan komposisi kimianya, batang pisang ini memiliki kandungan air 94,34\%, berdasarkan bahan kering batang pisang mengandung protein kasar 3,26\%, serat kasar 21,61\%, lemak kasar $0,35 \%$, abu $15,75 \%$, dan bahan ekstrak tanpa nitrogen 59,03\% (Laboratorium Nutrisi Ternak Ruminansia dan Kimia Makanan Ternak, 2011). Dilihat dari kandungan proteinnya, batang pisang memiliki kandungan protein kasar yang sangat rendah, diduga tidak dapat mencukupi kebutuhan pokok dan produksi bagi ternak seperti sapi potong, domba, dan kambing. Menurut NRC (2006), kebutuhan pakan berdasarkan bahan kering untuk domba dewasa adalah 3,5\% dari berat tubuhnya, dan kandungan protein kasarnya adalah 12\%. Septian, et.al. (2018) domba yang diberi pakan dengan kandungan protein $12 \%$ dan TDN $60 \%$ mampu menghasilkan pertambahan bobot badan harian sebanyak 106 gram/ekor/hari. Dengan demikian, dibutuhkan pakan substitusi untuk mencukupi kebutuhan pakan ternaknya. Salah satu cara untuk menyubstitusi kebutuhan pakan adalah dengan menggunakan konsentrat. Konsentrat adalah makanan penguat yang ditinggikan beberapa kandungan zat makanannya.

Pemberian pakan secara segaran atau dengan metode cut and carry, dinilai cukup menyulitkan peternak yang pada dasarnya hanya menjadikan beternak sebagai usaha sampingan, sehingga sumberdaya dan tenaga yang diberikan adalah sisa dari usaha utama. Perlu metode lain agar permasalahan tersebut dapat ditanggulangi. Pengolahan pakan secara fermentasi dinilai dapat meringankan beban kerja peternak, di mana peternak hanya perlu mencari hijauan sekali kemudian tidak perlu lagi mencari untuk beberapa hari ke depan, sehingga peternak dapat fokus di bidang usaha lainnya. Pakan yang difermentasi adalah pakan lengkap yang terdiri dari hijauan segar berupa rumput dan leguminosa, dengan bahan pakan penyusun konsentrat, seperti dedak, onggok, ampas jagung, kulit kopi, bungkil kedelai, ampas kecap, molases, dan bahan lainnya sesuai dengan bahan yang tersedia di lingkungan peternakan. Menurut Hartadi dkk. (2011), pakan komplit merupakan pakan yang cukup mengandung nutrien untuk ternak dalam tingkat fisiologis tertentu yang dibentuk dan diberikan sebagai satu-satunya pakan yang mampu memenuhi kebutuhan hidup pokok dan produksi tanpa tambahan substansi lain kecuali air. Pemberian pakan dengan sistem pakan lengkap komplit (lengkap) akan terhindar dari seleksi pakan sehingga sebagian besar pakan akan dapat dikonsumsi dan cenderung tidak selektif saat makan (Munawaroh, dkk.,2015).

Pakan lengkap terfermentasi mengandung kandungan nutrien yang lengkap ditambah adanya aditif berupa probiotik mampu membantu proses pencernaan pada ternak, sehingga pertumbuhan ternak akan semakin baik.

Mitra yang dijadikan objek PKM adalah Kelompok Tani Ternak Karya Makmur Desa Gunungpring, Kecamatan Muntilan, Kabupaten Magelang. Pemilihan lokasi berdasarkan permintaan kelompok tani ternak dan rekomendasi dari LPPM PMP Universitas Tidar, serta lokasi yang mendukung untuk pengembangan ternak domba dan kambing di mana di Kecamatan Muntilan terdapat Pasar Hewan Muntilan sehingga akan memudahkan masyarakat dalam penjualan ternaknya di kemudian hari. Selain itu terdapat banyak penggilingan padi di mana produk samping dari industri penggilingan padi yaitu dedak dapat dimanfaatkan sebagai pakan tambahan untuk domba dan kambing.

Data populasi domba dan kambing di Kecamatan Muntilan pada tahun 2019 adalah sebanyak 1637 ekor, Data populasi domba dan kambing pada kelompok tersebut sebanyak 65 ekor yang dimiliki oleh 13 orang. Kepemilikan perorangan bervariasi mulai dari 1 ekor hingga 20 ekor per orang, dengan rata-rata kepemilikan 5 ekor. Kondisi lingkungan dan objek PKM berada di daerah dengan ketinggian kuranglebih 400 MDPL dengan curah hujan berkisar $2800 \mathrm{~mm}$ dan suhu rata rata $30^{\circ} \mathrm{C}$ serta memiliki luas 217,49 ha. 


\section{Materi dan Metode Pelaksanaan}

Pelaksanaan Kegiatan dilakukan selama 2 bulan dari bulan Juni-Agustus 2020. Kegiatan ini dirancang dalam empat tahap yaitu tahap penjajakan, persiapan, pelaksanaan, dan evaluasi kegiatan. Seluruh kegiatan penyuluhan dan pembinaan dilakukan di Kelompok Tani Ternak Karya Makmur Desa Gunungpring Kecamatan Muntilan Kabupaten Magelang, dengan melibatkan peternak dan mahasiswa. Metode yang dilakukan dengan cara penyuluhan dan pelatihan pembuatan pakan lengkap terfermentasi. Tahap penjajakan dilakukan selama satu pekan yaitu pada tanggal 25 Juni s/d 2 Juli 2020. Tahap penjajakan dilakukan oleh tim PKM yaitu dengan menentukan lokasi dan perencanaan pengabdian dengan calon mitra. Kegiatan tahap persiapan dilakukan selama satu pekan yaitu pada tanggal 19 Juli s/d 25 Juli 2020, tahap persiapan dilakukan oleh tim PKM dan dibantu oleh mahasiswa untuk mempersiapkan lokasi penyuluhan, membuat dan menyebar undangan penyuluhan.

Kegiatan penyuluhan dilaksanakan pada tanggal 26 Juli 2020 bertempat di SD Negeri 1 Gunungpring pada pukul 09.00-14.00 WIB dengan jumlah peserta sebanyak 15 orang yang merupakan anggota Kelompok Tani Ternak Karya Makmur serta dihadiri oleh Kepala Desa Gunungpring dan para mahasiswa. Materi yang disampaikan adalah manajemen pemeliharaan, pengenalan bahan pakan, jenis-jenis hijauan pakan, teknologi pengolahan pakan dengan metode fermentasi pakan lengkap.

Kegiatan pelatihan atau praktik pembuatan fermentasi pakan lengkap dilaksanakan pada tanggal 2 Agustus 2020 pukul 10.00-15.00 WIB bertempat di pekarangan rumah milik Bapak Anang selaku ketua kelompok Karya Makmur Dusun Wonosari Desa Gunungpring dihadiri oleh 13 peserta, 8 orang mahasiswa, serta 3 orang tim PKM.

\section{Metode Pelaksanaan Kegiatan}

Metode pelaksanaan yang digunakan untuk mencapai tujuan PKM adalah dengan metode kuesioner, ceramah dan praktik uji coba. Metode ceramah dilakukan di ruang kelas SD Negeri 1 Gunungpring dan di rumah milik Bapak Anang. Peserta yang hadir disediakan tempat duduk dan meja belajar, Sebelum masuk pada materi, peserta diberikan selebaran kuesioner untuk diisi guna mengetahui pengetahuan dasar peserta terhadap ilmu dasar beternak domba dan kambing. Materi yang disampaikan mengenai pemeliharaan, pengenalan bahan pakan, jenis-jenis hijauan pakan, kebutuhan nutrien pada domba dan kambing, dan teknologi pengolahan pakan dengan metode fermentasi pakan lengkap, serta teknik evaluasi pakan fermentasi. Alat bantu yang digunakan adalah laptop, proyektor, layer, dan pelantang suara. Akhir dari pemaparan dilanjutkan dengan diskusi dan tanya jawab.

\section{Langka-langkah Kegiatan}

Kegiatan PKM dibagi dalam beberapa tahap yaitu:

\section{Tahap Penjajakan}

Inventarisasi permasalahan yang terjadi, potensi dan kelayakan wilayah untuk dijadikan sebagai lokasi PKM, dan respons masyarakat terhadap rencana kegiatan PKM.

\section{Tahap Persiapan}

Inventarisasi ketersediaan bahan baku penyusun ransum komplit, seperti rumput, leguminosa, dedak, dan konsentrat, serta ketersediaan alat-alat. Data yang diperoleh berupa bahan baku penyusun ransum komplit, harga bahan baku, sumber bahan, lokasi pengambilan bahan. Mengetahui ketersediaan bahan-bahan tersebut guna untuk menentukan struktur formulasi fermentasi pakan lengkap.

\section{Tahap Pelaksanaan}

Tahap pelaksanaan merupakan kegiatan penyuluhan dan praktik pembuatan fermentasi pakan lengkap. Kegiatan ini dilakukan dengan metode pre test, ceramah, praktik dan post test. Sebelum penyampaian materi, peserta diberi kuesioner untuk mengukur pengetahuan awal dan pengalaman peserta mengenai pengolahan pakan ternak. Materi yang disampaikan adalah: 1) Manajemen pemeliharaan domba dan kambing, 2) pengenalan bahan-bahan pakan, 3) jenis-jenis hijauan pakan, 4) kebutuhan pakan dan nutrien domba dan kambing, 5) teknologi pengolahan pakan dengan metode fermentasi pakan lengkap, 6) Teknik evaluasi pakan fermentasi. Luaran dari penyampaian materi adalah meningkatnya pengetahuan peserta mengenai manajemen pemeliharaan ternak, peserta mengetahui jenis-jenis bahan pakan, jenis-jenis hijauan pakan ternak, kebutuhan pakan dan nutrien, mengetahui cara pembuatan 
fermentasi pakan lengkap, serta mengetahui cara mengevaluasi pakan fermentasi.

Pada tahap praktik peserta membuat pakan olahan berupa fermentasi pakan lengkap. Kegiatan ini dilaksanakan di halaman rumah milik Bapak Anang dan peserta terlibat langsung dalam pembuatan fermentasi pakan lengkap. Bahan yang digunakan dalam membuat pakan lengkap terfermentasi di antaranya: 1) hijauan pakan berupa rerumputan, 2) konsentrat, perbandingan konsentrat dengan hijauan yaitu 30:70 berdasarkan bahan kering, 3) molases sebanyak $1 \%$ dari ransum (hijauan dan konsentrat berdasarkan bahan kering), 4) mineral $0,5 \%$ dari ransum, dan 5) probiotik merk Heryaki sebanyak $0,5 \%$ dari ransum. Molases, mineral, dan probiotik ditimbang sesuai dengan perhitungan lalu dicampurkan dan diaduk hingga homogen, setelah itu dicampurkan dengan konsentrat yang telah ditimbang sesuai dengan perhitungan dan diaduk hingga homogen. Campuran-campuran tersebut dicampurkan dan diaduk dengan hijauan yang telah ditimbang dan dihamparkan di atas terpal hingga homogen. Bahan-bahan tersebut kemudian dimasukkan ke dalam silo dan dipadatkan guna mengurangi kadar oksigen di dalam silo. Olahan tersebut difermentasi secara anaerob selama 7 hari. Lama fermentasi selama 7 hari berdasarkan hasil penelitian dari Setiyawan dan Thiasari (2016) di mana efektivitas mikroba dalam pembuatan total mixed ration berbasis pucuk tebu terjadi pada hari ke 7. Pembuatan pakan lengkap terfermentasi dinilai cukup selama 7 hari dengan bantuan mikroba probiotik.

Tahap 4 (Evaluasi pakan lengkap terfermentasi)

Setelah proses fermentasi selesai maka hari ke 7 silo dibuka dan pakan lengkap terfermentasi dilakukan proses evaluasi secara organoleptik dan diujicobakan pada ternak. Sebelum diujicobakan, pakan lengkap terfermentasi tersebut dianginkan hingga bau amoniaknya hilang, kemudian diberikan pada beberapa ternak untuk melihat tingkat kesukaan ternak pada pakan yang telah dibuat.

Tahap 5 (Evaluasi peserta)
Tahap terakhir adalah evaluasi terhadap peserta atau post test yang dilakukan kepada peserta untuk melihat keberhasilan penyuluhan yang dilihat dari respons peserta dan kemampuan menjawab pertanyaan dari diskusi setelah rangkaian penyuluhan berakhir serta melihat upaya keberlangsungan kegiatan yang dilakukan oleh peserta.

\section{Hasil dan pembahasan}

Kegiatan PKM yang dilaksanakan selama 2 bulan dari bulan Juni hingga Agustus 2020 berjalan dengan lancar. Masyarakat mendapatkan pengetahuan tambahan terkait dengan pemeliharaan domba dan kambing secara umum, serta mampu membuat pakan olahan berupa fermentasi pakan lengkap. Kegiatan tersebut merupakan upaya untuk meningkatkan produksi ternak dan meringankan beban peternak dalam mencukupi pakan ternaknya.

Pada tahap awal pengabdian yaitu dilakukan proses penjajakan dengan Desa setempat dan perwakilan tokoh masyarakat guna mengetahui potensi wilayah dan daya dukung masyarakat terhadap akan dilaksanakannya program pengabdian atau PKM. Hasil penjajakan menunjukkan bahwa secara umum Desa dan tokoh masyarakat Gunungpring sangat mendukung dengan adanya program PKM ini. Dengan demikian maka dilakukan tahap selanjutnya yaitu tahap persiapan untuk menginventarisasi bahan dan peralatan yang akan digunakan. Kegiatan ini Tim Dosen dibantu oleh mahasiswa untuk mempersiapkan segala kebutuhan untuk dilakukannya penyuluhan. Bahan dan alat yang telah disiapkan adalah hijauan pakan yang terdiri dari rumput lapang, beberapa jenis leguminosa, ramban, konsentrat, molases, mineral, dan mikroba probiotik.

Tahap selanjutnya adalah tahap inti yaitu pelaksanaan penyuluhan. Sebelum dilaksanakannya penyuluhan atau penyampaian materi, peserta diberikan pre test kuesioner untuk diketahui pengetahuan awal dan pengalaman peserta mengenai pengolahan pakan ternak. 
Tabel 1. Hasil Evaluasi Terhadap Peserta Program Kemitraan Masyarakat

\begin{tabular}{|c|c|c|c|}
\hline No & Indikator & Sebelum Kegiatan & Setelah Kegiatan \\
\hline 1 & $\begin{array}{l}\text { Pengetahuan tentang Manajemen } \\
\text { Pemeliharaan Domba dan Kambing }\end{array}$ & $\begin{array}{l}36,67 \% \text { (dari jumlah } \\
\text { peserta) }\end{array}$ & $\begin{array}{l}53.33 \% \text { (dari jumlah peserta) } \\
\text { peningkatan } 18,66 \%\end{array}$ \\
\hline 2 & $\begin{array}{l}\text { Pengetahuan peserta tentang jenis- } \\
\text { jenis bahan pakan dan hijauan pakan }\end{array}$ & $\begin{array}{l}36,67 \% \text { (dari jumlah } \\
\text { peserta) }\end{array}$ & $\begin{array}{l}66,67 \% \text { (dari jumlah } \\
\text { peserta) peningkatan } 30 \%\end{array}$ \\
\hline 3 & $\begin{array}{l}\text { Pengetahuan tentang pakan } \\
\text { fermentasi/silase }\end{array}$ & $\begin{array}{l}36,67 \% \text { (dari jumlah } \\
\text { peserta) }\end{array}$ & $\begin{array}{l}66,67 \% \text { (dari jumlah } \\
\text { peserta) peningkatan } 30 \%\end{array}$ \\
\hline 4 & $\begin{array}{l}\text { Pengetahuan tentang pakan komplit } \\
\text { terfermentasi }\end{array}$ & $\begin{array}{l}13,3 \% \text { (dari jumlah } \\
\text { peserta) }\end{array}$ & $\begin{array}{l}66,67 \% \text { (dari jumlah } \\
\text { peserta) peningkatan } 53,37 \%\end{array}$ \\
\hline 5 & $\begin{array}{l}\text { Pengalaman membuat pakan } \\
\text { fermentasi }\end{array}$ & $\begin{array}{l}33,33 \% \text { (dari jumlah } \\
\text { peserta) }\end{array}$ & $\begin{array}{l}53,33 \% \text { (dari jumlah } \\
\text { peserta) peningkatan } 20 \%\end{array}$ \\
\hline 6 & Intensitas Ngarit & $\begin{array}{l}100 \% \text { (dari jumlah } \\
\text { peserta) Setiap Hari }\end{array}$ & $\begin{array}{l}66,67 \% \text { (Dari jumlah } \\
\text { peserta) setiap hari, } \\
\text { penurunan } 33,33 \%\end{array}$ \\
\hline
\end{tabular}

Kegiatan penyuluhan dilaksanakan di SD Negeri 1 Gunungpring, dihadiri oleh 15 peserta yang di antaranya adalah 13 orang anggota Tani ternak Karya Makmur. Peserta seluruhnya merupakan laki-laki dengan rata-rata berumur produktif yaitu 47,72 tahun. Penyuluhan dilaksanakan guna meningkatkan wawasan peserta mengenai manajemen pemeliharaan domba dan kambing, jenis-jenis pakan ternak dan hijauan makanan ternak, dan cara pembuatan pakan lengkap terfermentasi.

Materi pertama disampaikan oleh Yosephin Laura R.E.N, S.Pt., M.Sc. yang menjelaskan mengenai manajemen pemeliharaan yaitu meliputi kegiatan rutin yang harus dilakukan dalam memelihara ternak, seperti manajemen perkandangan di mana kandang merupakan rumah tempat hidup kambing sehingga harus dibuat nyaman, baik dari aspek desainnya, maupun lokasinya. Fungsi kendang adalah melindungi ternak dari cuaca panas, hujan, serangan predator pemangsa, dan memudahkan pemilik dalam pengawasan (Ilham dkk, 2018). Manajemen pemilihan bibit di mana diperlukan seleksi dalam menentukan calon bibit. Seleksi dilakukan dengan memilih ternak kambing yang sesuai dengan kriteria peternak. Tujuan seleksi adalah meningkatkan frekuensi gen-gen yang diinginkan (Noor, 2008). Domba atau kambing betina yang tidak memiliki kriteria tidak akan dijadikan sebagai indukan melainkan harus digantikan dengan betina baru, begitu pula dengan domba atau kambing jantan. Peningkatan produktivitas domba lokal perlu dilakukan dengan perbaikan manajemen, baik manajemen pakan maupun pemeliharaan (Nurmi, 2016). Manajemen pemberian pakan, dijelaskan mengenai kebutuhan pakan ternak pada fase-fase tertentu dan waktu pemberian pakan yang baik. Peserta diberikan pula diktat mengenai materi manajemen pemeliharaan ternak. Pada materi kedua peserta dijelaskan mengenai jenis-jenis bahan pakan berdasarkan jenis dan kelasnya serta zat pembatas dalam penggunaan bahan pakan, kebutuhan pakan pada berbagai fase pertumbuhan. Hartadi (2008) mengatakan, bahan pakan dikelompokkan dalam delapan kelas berdasarkan karakteristik fisik dan kimianya yaitu kelas 1 (hijauan kering dan jerami kering), kelas 2 (hijauan segar), kelas 3 (silase selain silase ikan dan biji-bijian), kelas 4 (sumber energi), kelas 5 (sumber protein), kelas 6 (sumber mineral), kelas 7 (sumber vitamin) dan kelas 8 (aditif pakan).

Materi ketiga dijelaskan mengenai jenisjenis hijauan pakan ternak. Hijauan pakan ternak adalah semua bentuk bahan pakan berasal dari tanaman atau rumput termasuk leguminosa baik yang belum dipotong maupun yang dipotong dari lahan dalam keadaan segar (Akoso, 1996). Beberapa bahan pakan yang termasuk ke dalam hijauan pakan ternak adalah jenis-jenis rerumputan, leguminosa, dan ramban yang dapat diberikan pada ternak khususnya domba dan kambing. Materi kedua dan ketiga disampaikan oleh Nur Hidayah, S.Pt., M.Si. Materi keempat, dijelaskan mengenai teknologi pengolahan pakan dengan cara fermentasi anaerob atau silase, tepatnya adalah teknologi fermentasi pakan lengkap. Silase merupakan awetan basah segar yang disimpan dalam silo, sebuah tempat yang tertutup rapat dan kedap udara, pada kondisi anaerob. Pada suasana anaerob tersebut akan 
mempercepat pertumbuhan bakteri anaerob untuk membentuk asam laktat (Mugiawati, 2013). Asam laktat akan membuat suasana silase menjadi asam sehingga dapat terhidar dari mikroba pembusuk yang dapat merugikan seperti Entrobacteria dan Clostridia. Penggunaan pakan komplit lebih menjamin meratanya distribusi asupan harian ransum, agar fluktuasi kondisi ekosistem di dalam rumen diminimalisir (Tafaj et al., 2007). Materi keempat disampaikan oleh Dr. Lilis Hartati, S.Pt., M.Sc.

Pada kegiatan ini terjadi interaksi antara pemateri dan peserta. Peserta aktif bertanya perihal manajemen pemeliharaan dan pemberian pakan pada ternak, peserta yang berpengalaman dalam membuat pakan fermentasi memberikan pandangan dan menceritakan pengalamannya dalam membuat pakan olahan tersebut. Terjadi timbal balik yang sangat aktif antara peserta dengan pemateri dan peserta dengan peserta. Peserta lebih banyak bertanya perihal jenis-jenis bahan pakan, kelebihan dan kekurangan dari beberapa jenis bahan pakan, serta cara membuat pakan lengkap terfermentasi. Berdasarkan diskusi yang terjadi terlihat ada pengetahuan yang bertambah dari peserta perihal materimateri yang telah disampaikan. Suasana penyuluhan dapat dilihat pada Gambar 1 .

Kegiatan praktik pembuatan pakan lengkap terfermentasi dilaksanakan pada tanggal 2 Agustus 2020 bertempat di pekarangan rumah milik Bapak Anang yang merupakan ketua Tani Ternak Karya Makmur. Peserta Pengabdian antusias dalam melaksanakan pembuatan pakan lengkap terfermentasi. Peserta membuat pakan lengkap terfermentasi dipandu oleh Tim PKM dan Mahasiswa Program Studi Peternakan Fakultas Pertanian Universitas Tidar. Suasana pembuatan pakan lengkap terfermentasi dapat dilihat di Gambar 2.

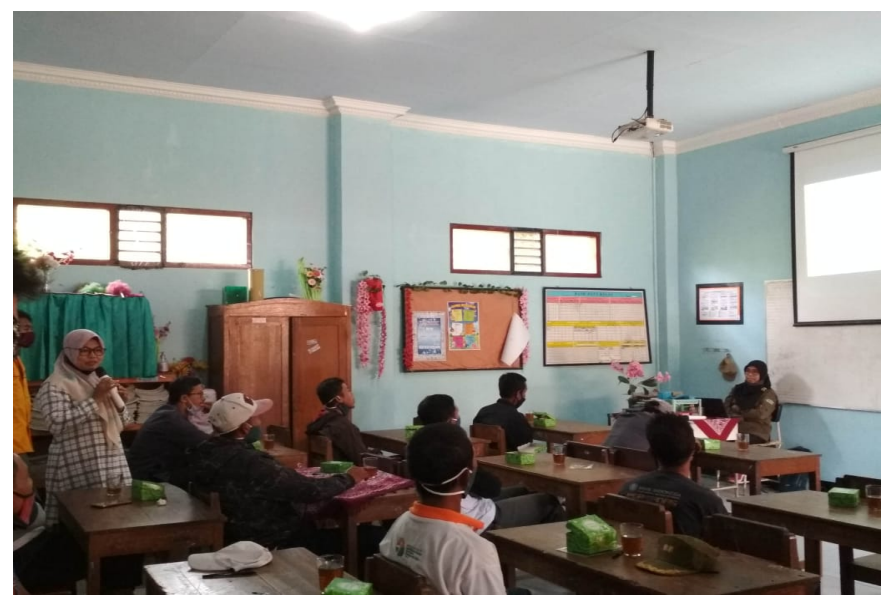

Gambar 1. Tim PKM sedang menyampaikan materi penyuluhan

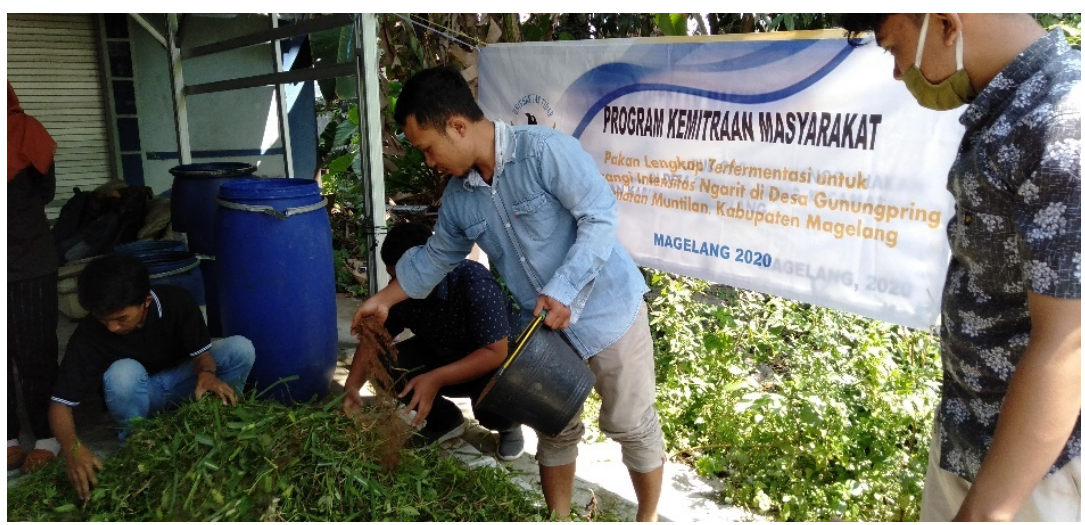

Gambar 2. Proses Pembuatan Pakan Lengkap Terfermentasi 
Pakan lengkap difermentasi selama 1 minggu, kemudian dilakukan evaluasi secara organoleptik dan uji coba pada ternak guna mengetahui kualitas pakan lengkap terfermentasi dan tingkat kesukaan ternak terhadap pakan tersebut. Hasil dari evaluasi secara organoleptik, dihasilkan silase yang harum, terasa sedikit manis, warna yang tidak terlalu berubah dari warna asalnya, serta disukai oleh ternak. Gambar pakan lengkap yang sudah jadi disajikan pada Gambar 6 dan gambar uji coba pada ternak disajikan pada Gambar 3.

Post test pada peserta pelatihan dilaksanakan setelah rangkaian penyuluhan dan evaluasi kualitas pakan lengkap terfermentasi selesai dilaksanakan. Post test dilakukan dengan cara wawancara dan diskusi langsung dengan peserta guna mengetahui perkembangan pengetahuan yang didapatkan oleh peserta pasca dilaksanakannya rangkaian penyuluhan. Dapat dilihat pada Tabel 1 bahwa secara keseluruhan ada peningkatan pengetahuan pada peserta terkait dengan materi-materi yang telah disampaikan.

Terdapat kenaikan 16,66\% dari jumlah awal peserta pada pengetahuan tentang manajemen pemeliharaan ternak. Sebelum dilakukan penyuluhan peternak tidak mengetahui manajemen yang baik dalam memelihara domba dan kambing, domba tidak pernah dimandikan dan dicukur, jarang melakukan sanitasi kendang, tidak mengetahui manajemen kesehatan ternak, serta pemberian pakan yang tidak beraturan dan tidak sesuai dengan kebutuhan ternak. Setelah dilakukan penyuluhan peternak jadi lebih mengetahui tata cara pemeliharaan ternak yang lebih baik, kendang menjadi lebih bersih, mengetahui tata cara pengobatan ternak sakit, pemberian pakan yang terjadwal dan penyediaannya sesuai dengan kebutuhan ternak baik secara kuantitas maupun kecukupan nutrien, dikarenakan peternak sudah menggunakan konsentrat sebagai pakan tambahan.

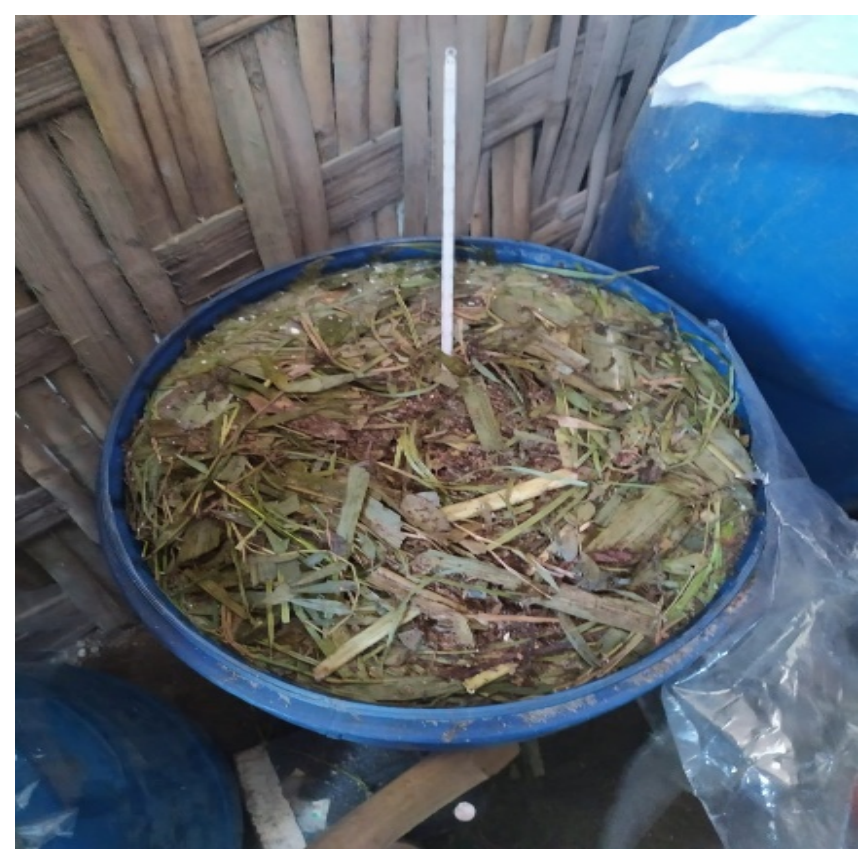

Gambar 3. Pakan lengkap terfermentasi 


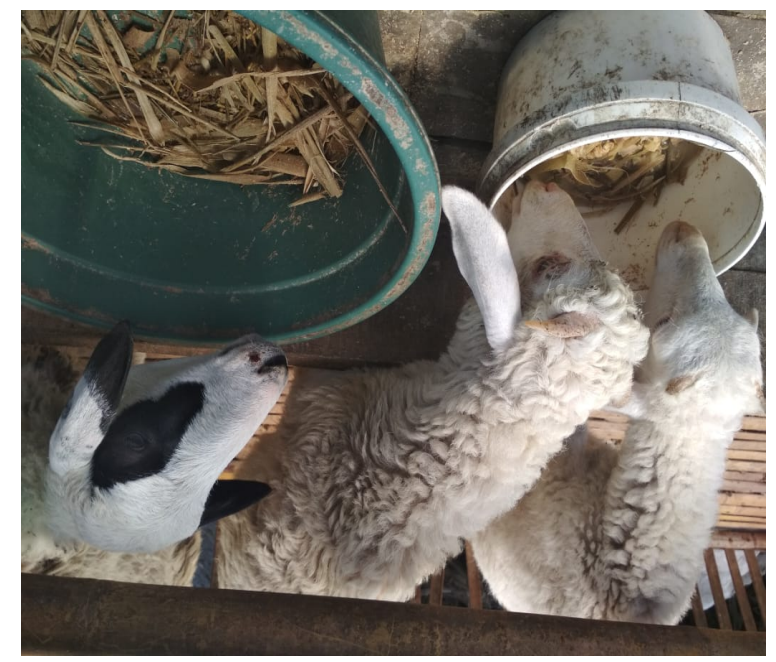

Gambar 4. Uji coba pakan lengkap terfermentasi pada ternak

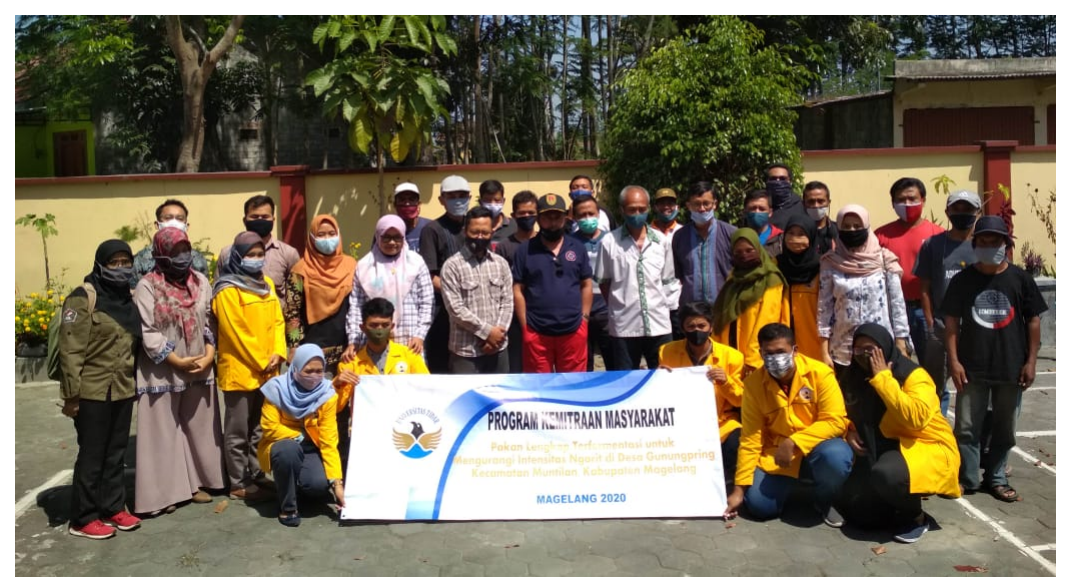

Gambar 5. Foto Bersama Setelah Kegiatan Penyuluhan

Terjadi kenaikan sebesar $30 \%$ dari jumlah awal peserta pada pengetahuan tentang bahan pakan dan hijauan pakan ternak. Sebelum dilakukan penyuluhan sebagian besar peternak hanya mengetahui bahwa pakan kambing dan domba hanya rumput dan dedaunan, rata-rata peternak tidak mengetahui istilah hijauan lainnya yaitu leguminosa. Setelah dilakukan penyuluhan peternak lebih mengetahui jenis-jenis bahan pakan dan hijauan pakan ternak.

Kenaikan sebesar 53.34\% dari jumlah awal peserta pada pengetahuan tentang pakan lengkap terfermentasi, kenaikan $20 \%$ dari jumlah awal peserta pada pengalaman peserta dalam membuat pakan komplit terfermentasi. Dengan adanya peningkatan ilmu pengetahuan dan pengalaman praktik membuat pakan lengkap terfermentasi. dapat menurunkan intensitas ngarit. Berdasarkan pemantauan keberlanjutan kegiatan, sebanyak 33,33\% peternak sudah mengurangi intensitas ngarit dari yang sebelumnya setiap hari, meskipun tidak ada data pasti terkait intensitas ngarit dalam satuan waktu tertentu. Keadaan ini didukung oleh kelompok ternak sudah mulai menanaman dan memanen hijauan rumput di lahan milik Desa Gunungpring. Dengan menggunakan hijauan hasil tanam maka kelompok mempunyai persediaan hijauan rumput guna ketahanan pakan. Rumput dipanen dan dibuat menjadi pakan fermentasi sebagai cadangan pakan dikemudian hari.

\section{Faktor Pendukung}

a. Kebijakan Desa Gunungpring yang telah meminjamkan lahannya untuk 
dijadikan lahan penanaman hijauan pakan.

b. Dengan kesadaran, Kelompok Tani Ternak Karya Makmur meminta untuk diberikan penyuluhan pengolahan pakan fermentasi.

c. Letak geografis yang strategis dekat dengan Kota dan terdapat Pasar Hewan, sehingga memudahkan peternak untuk memasarkan ternaknya.

\section{Faktor Penghambat}

a. Beternak masih sebagai usaha sampingan sehingga peternak tidak terfokus untuk beternak.

b. Usaha ternak masih terkendala oleh modal untuk pengadaan bibit ternak.

\section{Kesimpulan}

Secara Umum Masyarakat Desa Gunungpring antusias mengikuti kegiatan penyuluhan Pembuatan Pakan Lengkap terfermentasi. Kelompok Tani Ternak Karya Makmur mampu membuat pakan lengkap terfermentasi, serta mengaplikasikannya secara berkelanjutan.

\section{Ucapan Terima Kasih}

Penulis mengucapkan terima kasih terhadap LPPM PMP Universitas Tidar yang telah membiayai kegiatan Program Kemitraan Masyarakat tahun 2020 ini.

\section{Daftar Pustaka}

Akoso, B.T. 1996. Kesehatan Sapi. Kanisius, Yogyakarta

Hartadi, H., Kustantinah, R. E. Indarto, N. D. Dono, dan Zuprizal. 2008. Nutrisi Ternak Dasar. Bagian Nutrisi dan Makanan Ternak. Fakultas Peternakan Universitas Gadjah Mada. Yogyakarta.

Ilham, Fahrul., M. Mukhtar. 2018. Perbaikan Manajemen Pemeliharaan dalam rangka Mendukung Pembibitan Kambing Kacang bagi Warga di Kecamatan Bone Pantai Kabupaten Bone Bolango. JPKM, Vol.3, No.2, Maret 2018, Hal 143-156
Laboratorium Nutrisi Ternak Ruminansia dan Kimia Makanan Ternak. 2011. Kandungan Zat Makanan Batang Pisang. Fakultas Peternakan Universitas Padjadjaran. Sumedang.

Mide, M.Z. 2011. Penampilan sapi bali jantan muda yang diberikan ransum komplit.Pro. Seminar Nasional Peternakan Berkelanjutan III, UNPAD Bandung.

Mugiawati, R.E. 2013. Kadar Air dan pH Silase Rumput Gajah pada Hari ke-21 dengan Penambahan Jenis Aditif dan Bakteri Asam Laktat. Jurnal Ternak Ilmiah. 1 (1): 201-207

Munawaroh, L.L., I Gede Suparta Budisatria, Bambang Suwignyo. 2015. Pengaruh Pemberian Fermentasi Complete feed Berbasis Pakan Lokal Terhadap Konsumsi, Konversi Pakan dan Feed Cost Kambing Bligon Jantan. Buletin Peternakan Vol. 39 (3): 167-173, Oktober 2015

Noor, R.R. 2008. Genetika Ternak. Cetakan ke-4. Jakarta: PT Penebar Swadaya.

NRC. 2006. Nutrient Requirement of Sheep. National Academy Press. Washington, D.C.

Nurmi. 2016. Respons Fisiologis Domba Lokal dengan Perbedaan Waktu Pemberian Pakan Dan Panjang Pemotongan Bulu. JURNAL EKSAKTA VOLUME 1, 2016

Septian, M.H., I. Hernaman., R. Wiradimadja., F.T. Santoso. 2018. Performance and Diet Digestibility of Male Garut Lamb Fed Ipomea reptans Seed. Buletin Peternakan 42 (4): 1-5, November 2018

Setiyawan, A.I. dan N. Thiasari. 2016. Pengaruh Lama Pemeraman Terhadap Nilai Bahan Kering, Bahan Organik Dan Serat Kasar Pakan Komplit Berbasis Pucuk Tebu Terfermentasi Menggunakan Em-4 . Buana Sains Vol 16 No 2: $183-188$

Tafaj , M. Q. Zebeli, C. H. Baes, H. Steingass and W. Drochner. 2007. A meta-analysis examining effects of particle size of total mixed rations on intake, rumen digestion and milk production in high-yielding dairy cows at early lactation. Anim. Feed Sci. Technol. 138: 137-161. 